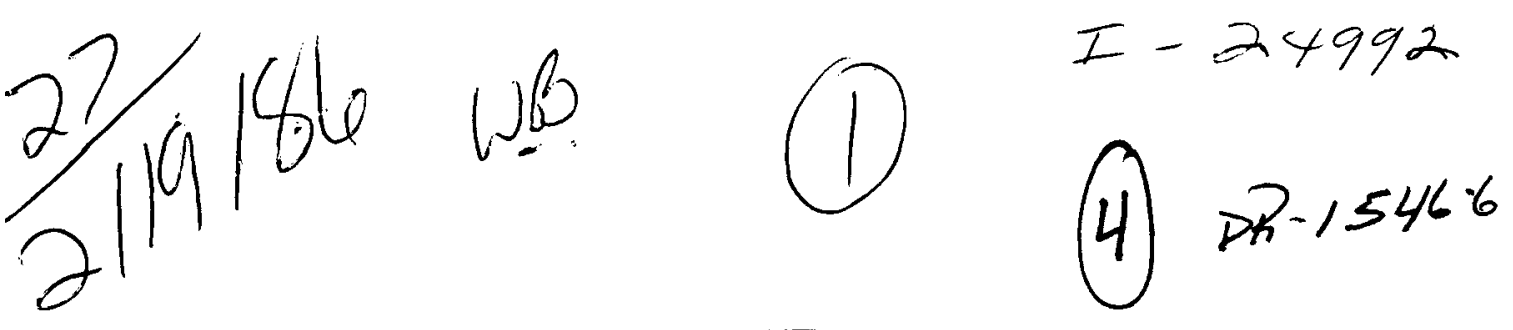

MARTIN MARIETRA

\title{
A Review of Spent-Fuel Photon and Neutron Source Spectra
}

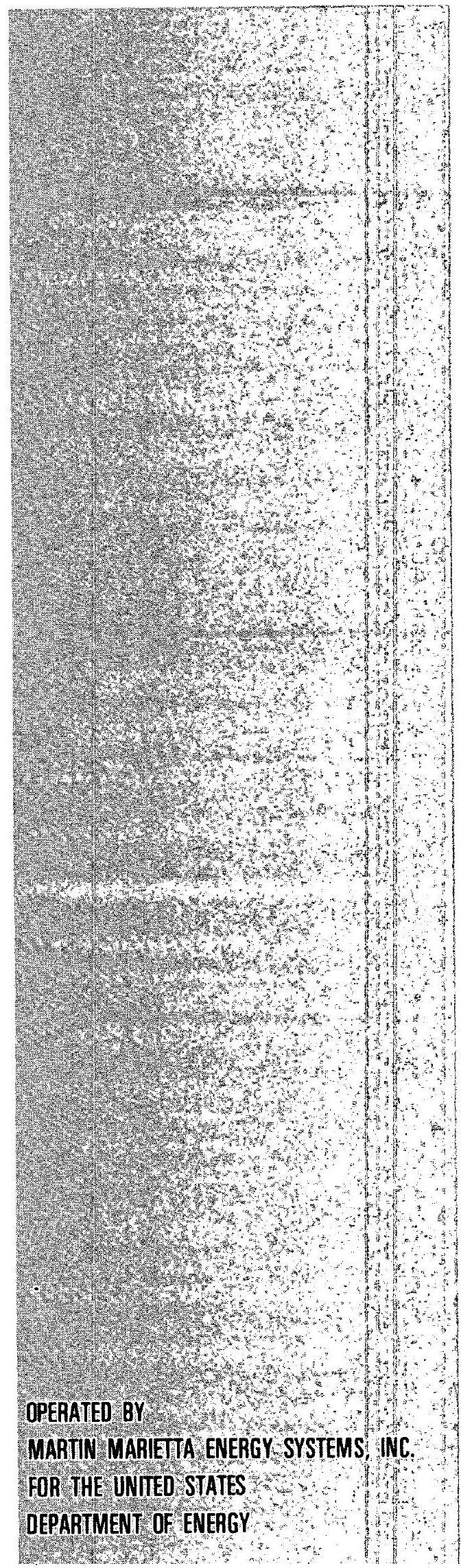
O. W. Hermann
C. W. Alexander \section{DO NOT MICROFILM
COVER}




\section{DISCLAIMER}

This report was prepared as an account of work sponsored by an agency of the United States Government. Neither the United States Government nor any agency Thereof, nor any of their employees, makes any warranty, express or implied, or assumes any legal liability or responsibility for the accuracy, completeness, or usefulness of any information, apparatus, product, or process disclosed, or represents that its use would not infringe privately owned rights. Reference herein to any specific commercial product, process, or service by trade name, trademark, manufacturer, or otherwise does not necessarily constitute or imply its endorsement, recommendation, or favoring by the United States Government or any agency thereof. The views and opinions of authors expressed herein do not necessarily state or reflect those of the United States Government or any agency thereof. 


\section{DISCLAIMER}

Portions of this document may be illegible in electronic image products. Images are produced from the best available original document. 
This report was prepared as an account of work sponsored by an agency of the United States Government. Neither the United States Government nor any agency thereof, nor any of their employees, makes any warranty, express or implied, or assumes any legal liability or responsibility for the accuracy, completeness, or usefulness of any information, apparatus, product, or process disclosed, or represents that its use would not infringe privately owned rights. Reference herein to any specific commercial product, process, or service by trade name, trademark, manufacturer, or otherwise, does not necessarily constitute or imply its endorsement, recommendation, or favoring by the United States Government or any agency thereof. The views and opinions of authors expressed herein do not necessarily state or reflect those of the United States Government or any agency thereof.

a

i.... 


\section{DISCLAIMER}

This report was prepared as an account of work sponsored by an agency of the United States Government. Neither the United States Government nor any agency thereof, nor any of their employees, makes any warranty, express or implied, or assumes any legal liability or responsibility for the accuracy, completeness, or usefulness of any information, apparatus, product, or process disclosed, or represents that its use would not infringe privately owned rights. Reference herein to any specific commercial product, process, or service by trade name, trademark, manufacturer, or otherwise does not necessarily constitute or imply its endorsement, recommendation, or favoring by the United States Government or any agency thereof. The views and opinions of authors expressed herein do not necessarily state or reflect those of the United States Government or any agency thereof.

IRNL/CSD/TM-205

Distribution Category: GM

Computing and Telecommunications Division

A REVIEW OF SPENT-FUEL PHOTON AND NEUTRON SOURCE SPECTRA

O. W. Hermann

C. W. Alexander

Chemical Technology Division

Date Published - January 1986

NOTICE: This document contains information of a preliminary nature. It is subject to revision or correction and therefore does not represent a final report.

This document is

Prepared by the

OAK RIDGE NATIONAL LABORATORY

Oak R1dge, Tennessee 37831

operated by

MARTIN MARIETTA ENERGY SYSTEMS, INC.

for the

U. S. DEPARTMENT OF ENERGY

under Contract No. DE-AC05-84OR21400

\section{PUBLICLY RELEASABLE}



TABLE OF CONTENTS

Page

LIST OF FIGURES. . . . . . . . . . . . . . . . . v v

ACKNOWLEDGMENTS. . . . . . . . . . . . . . . . vii

ABSTRACT . . . . . . . . . . . . . . . . . IX

1. INTRODUCTION . . . . . . . . . . . . . . . . . 1

2. NUCLIDE DEPLETION AND DECAY CODES . . . . . . . . . . . 1

2.1. DEPLETION AND DECAY MODEL . . . . . . . . . . . . . 1

2.2. DECAY AND CROSS-SECTION LIBRARIES . . . . . . . . . . . 2

3. PHOTON SOURCE SPECTRA. . . . . . . . . . . . . . . 2

3.1. THE MASTER PHOTON DATA BASE . . . . . . . . . . . 2

3.1.1. Gamma Rays and X-rays from Delayed Decay ...... 3

3.1.2. Gamma Rays from (Alpha, n) Reactions and Spontaneous
Fission. . . . . . . . . . . . 3

3.1.3. Bremsstrahlung Production. . . . . . . . . 4

3.2. EXAMPLES OF PHOTON SPECTRA . . . . . . . . . . . 4

4. NEUTRON SOURCE SPECTRA . . . . . . . . . . . . . 12

4.1. DESCRIPTION OF SAS2 NEUTRON SOURCE SPECTRUM MODEL . . . • . 12

4.1.1. Spontaneous Fission Neutron Source Strength. . . . 12

4.1.2. (Alpha, $n$ ) Reaction Neutron Source Strength . . . . 12

4.1.3. Computing the Neutron Spectral Distribution. . . . 13

4.2. EXAMPLES OF NEUTRON SPECTRA . . . . . . . . . . . . 13

5. RANGE OF APPLICABILITY . . . . . . . . . . . 16

6. CONCLUSIONS. . . . . . . . . . . . . . . . 17

7. REFERENCES . . . . . . . . . . . . . . . 18 

LIST OF FIGURES

Page

Figure 1. Fission Product Photon Spectra at Four Different

Cooling Times................ 5

Figure 2. Examples of Chief Contributors to Groups in the Spectra

of Figure 1................. . . 6

Figure 3. Photon Spectrum from all Nuclides in a PWR Spent-Fuel Assembly ................... 9

Figure 4. Part of Spectrum, Comparing Intensities for Different Energy-Group Widths. . . . . . . . . . 10

Figure 5. Examples of Data for ${ }^{134} \mathrm{Cs},{ }^{140} \mathrm{La}$ and $144 \mathrm{Pr}$ in the Master Photon Data Base. . . . . . . . . 11

Figure 6. Neutron Source Spectrum in the 27-Group Structure of a SCALE Library. ........... 14

Figure 7. Neutron Source Spectrum from a 1-Kilogram Mass of

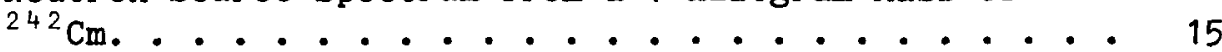




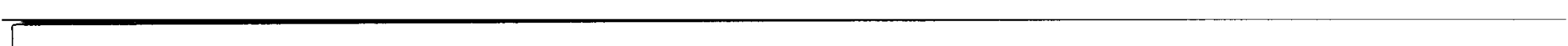


ACKNOWLEDGMENTS

A large number of persons contributed, either directly or indirectly, to the development reported here. The authors are grateful to all of them for their excellent work, even though each person could not be individually mentioned.

In particular, we gratefully acknowledge the following: M. J. Bell of the Nuclear Regulatory Commission, who wrote the original ORIGEN code; A. G. Croff, for developing ORIGEN2; M. A. Bjerke, A. G. Croff, C. W. Kee, G. W. Morrison and J. C. Ryman, for their contributions to the ORIGEN2 and ORIGEN-S libraries; W. B. Ewbanks, M. J. Martin and their associates, for producing the Nuclear Structure Data File; N. B. Gove, L. T. Dillman and R. L. Haese, for preparing the Master Photon Data Base; J. K. Bair and J. G. del Campo, for their development of neutron yield data; D. L. Johnson of the Hanford Engineering Development Laboratory for his neutron data contributions; D. L. Stoddard and associates of the Savannah River Laboratory for their production of spectral data; and R. M. Westfall, G. E. Whitesides, K. J. Notz and J. O. Blomeke for their guidance and supervision of this computational project.

We are very grateful to J. C. Ryman and A. G. Croff for their review of this document.

Also, we wish to thank $J$. Hamby for typing this manuscript. 


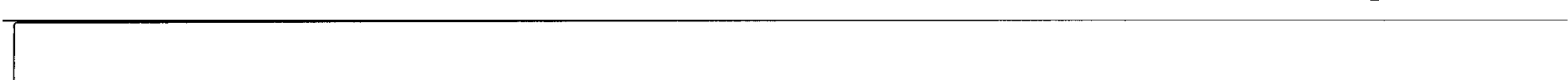


The calculations of spent-fuel photon and neutron spectra have been significantly improved over the past several years. Methods for performing these computations at ORNL have been implemented in the ORIGEN2 and ORIGEN-S codes and the SAS2 control module of the SCALE system. The codes use photon data for delayed gamma rays, $x$-rays, spontaneous fission gamma rays, (alpha, $n$ ) reaction gamma rays, bremsstrahlung and decay constants, taken mainly from the Evaluated Nuclear Data Structure File. The data for neutron source strengths and spectral distributions of spontaneous fission and (alpha, $n$ ) reactions were compiled from several different research projects.

Brief discussions of the codes, the spectral data and the range of applicability are presented. Also, several examples of spent-fuel photon and neutron spectra are included. 


\title{
A REVIEW OF SPENT-FUEL PHOTON AND NEUTRON SOURCE SPECTRA
}

\author{
1. INTRODUCTION
}

Proper radiation protection is a primary objective in the transportation, processing or storage of irradiated reactor fuel. The designing of adequate shielding to provide this protection requires appropriate knowledge of the radiation source in spent fuel. Since the gamma ray and neutron interaction probabilities associated with shielding materials depend substantially upon the energies of the photons and neutrons, it is important to describe these sources in terms of energy distributions, i.e. their source spectra. The computations of spent fuel photon and neutron source spectra have been appreciably improved at ORNL over the last several years.

The methods reviewed here include the calculation of spent-fuel isotopic compositions and the subsequent determination of the associated photon and neutron source spectra. Examples of various source spectra, computed by these methods, also, are presented.

\section{NUCLIDE DEPLETION AND DECAY CODES}

The nuclide composition of spent fuel may be computed by either ORIGEN2 ${ }^{1}$ or ORIGEN-S ${ }^{2}$ (two versions of the ORIGEN code ${ }^{3}$ ) or the SAS2 control module of the SCALE system, ${ }^{4}$ which uses ORIGEN-S. These codes basically use the same matrix-exponential-expansion model, but apply different approaches in the production of cross-section constants for their libraries.

\subsection{DEPLETION AND DECAY MODEL}

The main model used by these codes is briefly described below. The rate of change of any nuclide, $N$, at time, $t$, is:

$$
d N(t) / d t=\text { Formation Rate - Removal Rate. }
$$

Formation rates are derived from either decay rates of parents to $N$ or neutron reaction rates of target isotopes producing $\mathrm{N}$ from the exposure to reactor flux. Removal rates are either decay or neutron reaction rates of nuclide $N$. Then, the derivative $\mathrm{dN}_{i}(t) / d t$ of Equation (1), for any $N_{i}$, simply equals the sum of terms, $a_{i j} N_{j}(t)$, where $a_{i j}$ is the transition rate constant for producing $N_{i}$ from $N_{j}$. Also, if $i=1$ to $I$, the set of differential equations for $I$ nuclides in the reactor fuel may be cast in matrix notation as,

$$
d \tilde{N}(t) / d t=\tilde{\widetilde{N}} \tilde{N}(t) \text {. }
$$

where $\tilde{N}$ is the vector or elements $N_{i}$, in units of atoms, and $\tilde{A}$ is the matrix of elements $a_{i j}$. The solution to Equation (2) is 


$$
\tilde{N}(t)=\exp (\tilde{A} t) \tilde{N}(0),
$$

which is computed by the codes through a unique recursion relationship for calculating successive terms of the series expansion for exp( $\left.{ }^{\mathrm{A}} t\right)$.

\subsection{DECAY AND CROSS-SECTION LIBRARIES}

There are approximately 1300 different nuclides in the ORIGEN2 and ORIGEN-S libraries. The decay data in these libraries have been significantly improved from the data of the original ORIGEN code. The sources of the decay data have been documented for both ORIGEN2 ${ }^{5}$ and ORIGEN-S. ${ }^{6}$ While the data for some of the nuclides of less importance may differ, the two libraries contain identical decay data for the nuclides producing essentially all of the spent-fuel source intensity.

There is a considerable difference in the methods used by the codes in the production of their cross-section libaries. ORIGEN2 uses libraries of burnup-dependent cross-section constants derived from separate reactor analyses for specific types of reactors and fuel compositions. ${ }^{7,8}, 9,10$ ORIGEN-S uses burnup- and reactor-dependent libraries produced by SAS2 or the code may be used directly with basic libraries. ${ }^{3}, 6,11,12$ The primary function of SAS2 is to compute photon and neutron dose rates from shipping casks containing spent-fuel assemblies. The spent-fuel composition of these assemblies, specified by the unit-cell description and operating history input to the case, is computed in a depletion analysis performed by functional modules of SCALE.

\section{PHOTON SOURCE SPECTRA}

One of the functions of ORIGEN2, ORIGEN-S and SAS2 is the determination of photon source spectra from spent fuel. These sources may be computed at various cooling times for fuel from different types of reactors, in addition to different fuel loadings and power histories. The data used by these codes, in converting the nuclide inventories of the spent fuel to a photon spectrum, is taken from the ORNL Master Photon Data Base. ${ }^{5}$ Photon spectra produced by ORIGEN2 have an energygroup-structure that is frequently used in shielding analyses. The energy-group-structure used by ORIGEN-S may be input by the user, whereas, SAS2 applies that of the photon cross-section library requested for the shielding analysis.

\subsection{THE MASTER PHOTON DATA BASE}

The Master Photon Data Base contains data from five different types of photon-production processes: 
- gamma rays and $\mathbf{x}$-rays from delayed radioactive decay,

- gamma rays from (alpha, $n$ ) reactions,

- prompt fission gamma rays from spontaneous fission,

- delayed gamma rays from spontaneous fission,

- bremsstrahlung from positron and electron deceleration.

3.1.1. Gamma Rays and X-rays from Delayed Decay

The predominant part of the photon source spectrum from spent fuel is from the gamma rays produced by the decay of fission and activation products. The energy-dependent photon-intensities for both the gammarays and $x$-rays, including that produced by internal conversion, were taken from the Evaluated Nuclear Structure Data File (ENSDF), ${ }^{13}, 14$ which contains photon data on more than 400 nuclides.

Photon intensities, $I$, in the data base and their associated energy, $E_{I}$, are converted to energy group intensities, $G$, by conserving energy. The following equation is applied for this adjustment:

$$
G=I\left(E_{I} / E_{G}\right) \text {, }
$$

where $E_{G}$ is the arithmetic average of the energy group boundaries.

\subsubsection{Gamma Rays from (Alpha, $n$ ) Reactions and Spontaneous Fission}

Many of the 1sotopes in the spent fuel emit alpha-particles that may interact with the ${ }^{17} 0$ and ${ }^{18} 0$ atoms in oxide fuel, producing neutrons and prompt gamma rays during the process. The measured gamma ray spectrum produced by the reaction of alpha-particles from ${ }^{2}{ }^{38} \mathrm{Pu}$ with ${ }^{18} 0$ atoms was used for developing ${ }^{5,15,16}$ approximate spectra for alphaemitters in the data base.

The spectral distribution of the prompt and delayed spontaneous fission photons are computed from equations fit to the photon spectrum from neutron-induced fission of ${ }^{235} \mathrm{U} .{ }^{17}$ The intensities of the spontaneous fission product gamma rays are assumed to be 0.75 times that from prompt fission photons. ${ }^{18}$

The photons from (alpha, $n$ ) reactions and spontaneous fissions, normally, are a very insignificant part of the source in spent fuel. After fission products are extracted from the heavy metals in a processing plant, however, the gamma ray production in the actinides from these reactions can become important. Also, essentially all of the low intensities above $4 \mathrm{MeV}$ in the spent fuel spectrum is due to spontaneous fission. 


\subsubsection{Bremsstrahlung Production}

A significant source of photons in spent fuel is the bremsstrahlung radiation, which is generated as a continuous spectrum when electrons or positrons are decelerated in the Coulomb field of nuclei. Thus, bremsstrahlung data for electron or positron emitters were included in the Master Photon Data Base. Since the theory indicates that only a relatively small bremsstrahlung intensity is derived from alpha-particles, it was not included.

First, in the determination of bremsstrahlung data, the continuous energy-dependent electron and positron spectra of the nuclide is computed from the Log-f Tables derived ${ }^{19}$ from theory of beta decay. This model, also, is used in producing average beta energies for ENSDF. Then, a model for computing the bremsstrahlung spectrum from the beta emission spectrum is applied. The details of this bremsstrahlung model are described in the documentation on the EDISTR code. ${ }^{20}$ While the calculation is patterned after that in a code developed by Van Tuyl, 21 it applies a more exact beta spectrum, improved cross sections, and the ionization energy loss accounts for differences between electrons and positrons.

The bremsstrahlung radiation is an important part of the total photon source spectrum from spent fuel. It has significant intensities for the energy range between 0 to $4 \mathrm{MeV}$. As the photon energy increases, the intensity from bremsstrahlung usually decreases more rapidly than that from delayed decay. Calculations, comparing the bremsstralung source with the total photon source, indicated about $1 / 3$ of the photons and from 7 to $10 \%$ of the total energy are from bremsstrahlung. By observing these spectra and the energy-group dose rates of a somewhat typical shielding problem, it was indicated that $10-20 \%$ of the total photon dose rate was due to bremsstrahlung radiation.

\subsection{EXAMPLES OF PHOTON SPECTRA}

Examples of photon source spectra and associated data are shown in Figs. 1-5. Fig. 1 was produced by ORIGEN2 for several cooling times for PWR fuel having a burnup of 33,000 MWd/MTU and an initial enrichment of 3.2 weight $\%{ }^{235} \mathrm{U}$. Energy midpoints of the group structure are listed in the first column and spectra are shown in columns under each cooling time. The principal nuclides contributing to groups at $1.25,1.75$ and $2.25 \mathrm{MeV}$ are shown in Fig. 2, based upon a print cutoff of $1 \%$ of the group intensity of any of the spectra. Fig. 3 shows the photon spectrum of a PWR assembly cooled to 90 days, as produced by SAS2. It includes sources from all nuclides in the composition of spent fuel, i.e. the fission products, the heavy metals, the clad and the structural materials. Fig. 4 is a plot comparing three broad groups of a PWR spent-fuel spectrum with that for the same source in $0.01 \mathrm{MeV}$ group intervals, as computed by ORIGEN-S. It illustrates the pronounced variations of the intensities in the detailed 
PHOTON SPECTRUM FOR FISSION PRODUCTS

DECAY OF SPENT PWR-U FUEL

18 GROUP PHOTON RELEASE RATES, PHOTONS/SECOND EMEAN

BASIS= ONE METRIC TON OF PWR-U FUEL:33,000 MWD/MTIHM

$\begin{array}{rrrrrrr} & \text { DISCHARGE } & 0.5 Y R & 1.0 Y R & 2.0 Y R & 5.0 Y R \\ 1.000 \mathrm{E}-02 & 2.185 \mathrm{E}+18 & 4.281 \mathrm{E}+16 & 2.714 \mathrm{E}+16 & 1.328 \mathrm{E}+16 & 3.230 \mathrm{E}+15 \\ 2.500 \mathrm{E}-02 & 5.723 \mathrm{E}+17 & 9.596 \mathrm{E}+15 & 6.079 \mathrm{E}+15 & 3.037 \mathrm{E}+15 & 7.709 \mathrm{E}+14 \\ 3.750 \mathrm{E}-02 & 4.659 \mathrm{E}+17 & 9.881 \mathrm{E}+15 & 6.335 \mathrm{E}+15 & 3.117 \mathrm{E}+15 & 8.224 \mathrm{E}+14 \\ 5.750 \mathrm{E}-02 & 4.701 \mathrm{E}+17 & 8.831 \mathrm{E}+15 & 5.674 \mathrm{E}+15 & 2.762 \mathrm{E}+15 & 6.399 \mathrm{E}+14 \\ 8.500 \mathrm{E}-02 & 3.456 \mathrm{E}+17 & 6.215 \mathrm{E}+15 & 4.024 \mathrm{E}+15 & 1.937 \mathrm{E}+15 & 4.240 \mathrm{E}+14 \\ 1.250 \mathrm{E}-01 & 3.710 \mathrm{E}+17 & 8.012 \mathrm{E}+15 & 4.783 \mathrm{E}+15 & 2.217 \mathrm{E}+15 & 4.322 \mathrm{E}+14 \\ 2.250 \mathrm{E}-01 & 7.975 \mathrm{E}+17 & 5.382 \mathrm{E}+15 & 3.498 \mathrm{E}+15 & 1.690 \mathrm{E}+15 & 3.594 \mathrm{E}+14 \\ 3.750 \mathrm{E}-01 & 5.930 \mathrm{E}+17 & 2.838 \mathrm{E}+15 & 1.889 \mathrm{E}+15 & 9.443 \mathrm{E}+14 & 2.115 \mathrm{E}+14 \\ 5.750 \mathrm{E}-01 & 9.733 \mathrm{E}+17 & 1.909 \mathrm{E}+16 & 1.389 \mathrm{E}+16 & 9.784 \mathrm{E}+15 & 5.112 \mathrm{E}+15 \\ 8.500 \mathrm{E}-01 & 1.011 \mathrm{E}+18 & 2.770 \mathrm{E}+16 & 7.634 \mathrm{E}+15 & 3.061 \mathrm{E}+15 & 1.106 \mathrm{E}+15 \\ 1.250 \mathrm{E}+00 & 5.650 \mathrm{E}+17 & 1.188 \mathrm{E}+15 & 8.949 \mathrm{E}+14 & 5.640 \mathrm{E}+14 & 2.272 \mathrm{E}+14 \\ 1.750 \mathrm{E}+00 & 2.120 \mathrm{E}+17 & 1.269 \mathrm{E}+14 & 8.407 \mathrm{E}+13 & 4.190 \mathrm{E}+13 & 8.411 \mathrm{E}+12 \\ 2.250 \mathrm{E}+00 & 1.062 \mathrm{E}+17 & 2.504 \mathrm{E}+14 & 1.615 \mathrm{E}+14 & 6.774 \mathrm{E}+13 & 5.146 \mathrm{E}+12 \\ 2.750 \mathrm{E}+00 & 4.547 \mathrm{E}+16 & 3.610 \mathrm{E}+12 & 2.458 \mathrm{E}+12 & 1.224 \mathrm{E}+12 & 1.524 \mathrm{E}+11 \\ 3.500 \mathrm{E}+00 & 2.288 \mathrm{E}+16 & 4.300 \mathrm{E}+11 & 3.042 \mathrm{E}+11 & 1.529 \mathrm{E}+11 & 1.943 \mathrm{E}+10 \\ 5.000 \mathrm{E}+00 & 1.001 \mathrm{E}+16 & 5.558 \mathrm{E}-05 & 5.629 \mathrm{E}-05 & 5.746 \mathrm{E}-05 & 5.957 \mathrm{E}-05 \\ 7.000 \mathrm{E}+00 & 8.968 \mathrm{E}+13 & 3.606 \mathrm{E}-06 & 3.652 \mathrm{E}-06 & 3.728 \mathrm{E}-06 & 3.865 \mathrm{E}-06 \\ 9.500 \mathrm{E}+00 & 1.911 \mathrm{E}+10 & 2.280 \mathrm{E}-07 & 2.310 \mathrm{E}-07 & 2.358 \mathrm{E}-07 & 2.444 \mathrm{E}-07 \\ \text { TOTAL } & 8.746 \mathrm{E}+18 & 1.419 \mathrm{E}+17 & 8.208 \mathrm{E}+16 & 4.250 \mathrm{E}+16 & 1.335 \mathrm{E}+16 \\ \text { MEV/SEC } & 3.549 \mathrm{E}+18 & 4.215 \mathrm{E}+16 & 1.953 \mathrm{E}+16 & 1.082 \mathrm{E}+16 & 4.560 \mathrm{E}+15\end{array}$

Figure 1. Fission Product Photon Spectra at Four Different Cooling Times. 
PRINCIPAL PHOTON SOURCES IN GROUP 11, PHOTONS/SEC

MEAN ENERGY $=1.250 \mathrm{MEV}$

\begin{tabular}{|c|c|c|c|c|c|}
\hline NUCLIDE & DISCHARGE & $0.5 \mathrm{YR}$ & 1.0YR & 2.0YR & 5.0YR \\
\hline KR 89 & $7.007 \mathrm{E}+15$ & 0.0 & 0.0 & 0.0 & 0.0 \\
\hline RB 89 & $2.806 \mathrm{E}+16$ & 0.0 & 0.0 & 0.0 & 0.0 \\
\hline $\mathrm{KR} 90$ & $1.138 E+16$ & 0.0 & 0.0 & 0.0 & 0.0 \\
\hline Y 90 & $4.936 \mathrm{E}+12$ & $4.626 E+12$ & $4.571 \mathrm{E}+12$ & $4.464 \mathrm{E}+12$ & $4.156 E+12$ \\
\hline SR 91 & $1.209 E+16$ & 0.0 & 0.0 & 0.0 & 0.0 \\
\hline Y 91 & 1. $271 E+14$ & $1.471 E+13$ & $1.690 \mathrm{E}+12$ & $2.231 \mathrm{E}+10$ & $5.137 E+04$ \\
\hline SR 92 & $4.511 \mathrm{E}+16$ & 0.0 & 0.0 & 0.0 & 0.0 \\
\hline Y 94 & $8.003 E+15$ & 0.0 & 0.0 & 0.0 & 0.0 \\
\hline M0101 & $2.316 \mathrm{E}+16$ & 0.0 & 0.0 & 0.0 & 0.0 \\
\hline TC102 & $7.051 E+15$ & 0.0 & 0.0 & 0.0 & 0.0 \\
\hline TC104 & $1.050 E+16$ & 0.0 & 0.0 & 0.0 & 0.0 \\
\hline RH106 & $6.230 E+14$ & $3.908 \mathrm{E}+14$ & $2.771 \mathrm{E}+14$ & $1 \cdot 393 E+14$ & $1.771 \mathrm{E}+13$ \\
\hline AG110M & $5.211 E+13$ & $3.140 E+13$ & $1.892 \mathrm{E}+13$ & $6.869 \mathrm{E}+12$ & $3.288 \mathrm{E}+11$ \\
\hline SB130M & $8.717 E+15$ & 0.0 & 0.0 & 0.0 & 0.0 \\
\hline SB131 & $8.185 E+15$ & 0.0 & 0.0 & 0.0 & 0.0 \\
\hline I132 & $1.268 \mathrm{E}+16$ & $1.719 \mathrm{E}-01$ & $2.300 \mathrm{E}-18$ & 0.0 & 0.0 \\
\hline TE133 & $1.011 \mathrm{E}+16$ & 0.0 & 0.0 & 0.0 & 0.0 \\
\hline I134 & $2.620 \mathrm{E}+16$ & 0.0 & 0.0 & 0.0 & 0.0 \\
\hline $\operatorname{cs} 134$ & $3 \cdot 362 E+14$ & $2.842 E+14$ & $2.402 E+14$ & $1.717 E+14$ & $6.262 E+13$ \\
\hline I135 & $5.203 \mathrm{E}+16$ & 0.0 & 0.0 & 0.0 & 0.0 \\
\hline I136 & $3 \cdot 352 E+16$ & 0.0 & 0.0 & 0.0 & 0.0 \\
\hline I136M & $2.105 E+16$ & 0.0 & 0.0 & 0.0 & 0.0 \\
\hline $\operatorname{cs} 138$ & $7.911 E+16$ & 0.0 & 0.0 & 0.0 & 0.0 \\
\hline XE139 & $5.743 \mathrm{E}+15$ & 0.0 & 0.0 & 0.0 & 0.0 \\
\hline CS139 & $7.234 E+15$ & 0.0 & 0.0 & 0.0 & 0.0 \\
\hline BA141 & $8.403 E+15$ & 0.0 & 0.0 & 0.0 & 0.0 \\
\hline BA1 42 & $2.670 \mathrm{E}+16$ & 0.0 & 0.0 & 0.0 & 0.0 \\
\hline LA142 & $1.050 \mathrm{E}+16$ & 0.0 & 0.0 & 0.0 & 0.0 \\
\hline PR144 & $3.960 E+14$ & $2.514 E+14$ & $1.611 E+14$ & $6.610 E+13$ & $4.569 E+12$ \\
\hline EU154 & $2.061 E+14$ & $1.980 E+14$ & $1.902 E+14$ & $1.755 E+14$ & $1.378 E+14$ \\
\hline
\end{tabular}

Figure 2. Examples of Chief Contributors to Groups in the Spectra of Figure 1. 
Figure 2 (cont'd)

PRINCIPAL PHOTON SOURCES IN GROUP 12, PHOTONS/SEC

MEAN ENERGY $=1.750 \mathrm{MEV}$

\begin{tabular}{|c|c|c|c|c|c|}
\hline \multicolumn{6}{|l|}{ NUCLIDE } \\
\hline & DISCHARGE & $0.5 \mathrm{YR}$ & 1.0YR & 2.0YR & $5.0 \mathrm{YR}$ \\
\hline KR 88 & $3.051 E+15$ & 0.0 & 0.0 & 0.0 & 0.0 \\
\hline RB 88 & $5.733 E+15$ & 0.0 & 0.0 & 0.0 & 0.0 \\
\hline KR 89 & $5.792 E+15$ & 0.0 & 0.0 & 0.0 & 0.0 \\
\hline KR 90 & $5.410 \mathrm{E}+15$ & 0.0 & 0.0 & 0.0 & 0.0 \\
\hline$Y 90$ & $3.851 E+11$ & $3.610 \mathrm{E}+11$ & $3.567 E+11$ & $3.483 E+11$ & $3.243 E+11$ \\
\hline Y 94 & $3.660 E+15$ & 0.0 & 0.0 & 0.0 & 0.0 \\
\hline M0101 & $8.335 E+15$ & 0.0 & 0.0 & 0.0 & 0.0 \\
\hline TC104 & $1.460 \mathrm{E}+16$ & 0.0 & 0.0 & 0.0 & 0.0 \\
\hline RH106 & $1.161 E+14$ & $7.282 E+13$ & $5.164 E+13$ & $2.596 E+13$ & $3.299 E+12$ \\
\hline AG110M & $2.013 E+13$ & $1.213 E+13$ & $7 \cdot 308 \mathrm{E}+12$ & $2.653 E+12$ & $1.270 \mathrm{E}+11$ \\
\hline SB124 & $2.511 E+13$ & $3.066 E+12$ & $3.743 E+11$ & $5.581 \mathrm{E}+09$ & $1.850 E+04$ \\
\hline SB131 & $5.415 E+15$ & 0.0 & 0.0 & 0.0 & 0.0 \\
\hline$S B 132$ & $2.255 E+15$ & 0.0 & 0.0 & 0.0 & 0.0 \\
\hline TE133 & $2.716 E+15$ & 0.0 & 0.0 & 0.0 & 0.0 \\
\hline TE133M & $2.953 E+15$ & 0.0 & 0.0 & 0.0 & 0.0 \\
\hline I134 & $1.183 E+16$ & 0.0 & 0.0 & 0.0 & 0.0 \\
\hline I135 & $1.697 E+16$ & 0.0 & 0.0 & 0.0 & 0.0 \\
\hline XE138 & $1.214 E+16$ & 0.0 & 0.0 & 0.0 & 0.0 \\
\hline XE139 & $3.733 E+15$ & 0.0 & 0.0 & 0.0 & 0.0 \\
\hline $\operatorname{cs} 139$ & $2.125 E+15$ & 0.0 & 0.0 & 0.0 & 0.0 \\
\hline LA1 40 & $5.808 \mathrm{E}+16$ & $3.243 E+12$ & $1.631 \mathrm{E}+08$ & $4.124 \mathrm{E}-01$ & 0.0 \\
\hline BA141 & $2.929 E+15$ & 0.0 & 0.0 & 0.0 & 0.0 \\
\hline LA142 & $1.276 E+16$ & 0.0 & 0.0 & 0.0 & 0.0 \\
\hline PR144 & $4.595 E+13$ & $2.917 E+13$ & $1.869 E+13$ & $7.670 \mathrm{E}+12$ & $5.301 E+11$ \\
\hline EU154 & $6.180 \mathrm{E}+12$ & $5.936 E+12$ & $5.702 E+12$ & $5.260 \mathrm{E}+12$ & $4.130 \mathrm{E}+12$ \\
\hline
\end{tabular}


Figure 2 (cont'd)

PRINCIPAL PHOTON SOURCES IN GROUP 13, PHOTONS/SEC

MEAN ENERGY $=2.250 \mathrm{MEV}$

NUCLIDE

$$
\begin{array}{lllll}
\text { DISCHARGE } & 0.5 \mathrm{YR} & 1.0 \mathrm{YR} & 2.0 \mathrm{YR} & 5.0 \mathrm{YR}
\end{array}
$$

$\begin{array}{llllll}\text { KR } 88 & 1.448 \mathrm{E}+16 & 0.0 & 0.0 & 0.0 & 0.0 \\ \text { KR 89 } & 1.664 \mathrm{E}+15 & 0.0 & 0.0 & 0.0 & 0.0 \\ \text { RB 89 } & 4.784 \mathrm{E}+15 & 0.0 & 0.0 & 0.0 & 0.0 \\ \text { Y 94 } & 1.329 \mathrm{E}+15 & 0.0 & 0.0 & 0.0 & 0.0 \\ \text { M0101 } & 5.625 \mathrm{E}+15 & 0.0 & 0.0 & 0.0 & 0.0 \\ \text { TC104 } & 3.877 \mathrm{E}+15 & 0.0 & 0.0 & 0.0 & 0.0 \\ \text { RH106 } & 3.578 \mathrm{E}+13 & 2.244 \mathrm{E}+13 & 1.591 \mathrm{E}+13 & 8.000 \mathrm{E}+12 & 1.017 \mathrm{E}+12 \\ \text { SB131 } & 2.608 \mathrm{E}+15 & 0.0 & 0.0 & 0.0 & 0.0 \\ \text { TE133M } & 1.764 \mathrm{E}+15 & 0.0 & 0.0 & 0.0 & 0.0 \\ \text { I135 } & 1.837 \mathrm{E}+15 & 0.0 & 0.0 & 0.0 & 0.0 \\ \text { I136 } & 6.306 \mathrm{E}+15 & 0.0 & 0.0 & 0.0 & 0.0 \\ \text { XE138 } & 1.256 \mathrm{E}+16 & 0.0 & 0.0 & 0.0 & 0.0 \\ \text { CS138 } & 1.062 \mathrm{E}+16 & 0.0 & 0.0 & 0.0 & 0.0 \\ \text { XE139 } & 2.462 \mathrm{E}+15 & 0.0 & 0.0 & 0.0 & 0.0 \\ \text { CS139 } & 1.588 \mathrm{E}+15 & 0.0 & 0.0 & 0.0 & 0.0 \\ \text { LA142 } & 2.058 \mathrm{E}+16 & 0.0 & 0.0 & 0.0 & 0.0 \\ \text { PR144 } & 3.579 \mathrm{E}+14 & 2.272 \mathrm{E}+14 & 1.456 \mathrm{E}+14 & 5.974 \mathrm{E}+13 & 4.129 \mathrm{E}+12 \\ \text { EU156 } & 1.233 \mathrm{E}+15 & 2.966 \mathrm{E}+11 & 7.109 \mathrm{E}+07 & 4.084 \mathrm{E}+00 & 0.0\end{array}$


GAMMA SOURCE SPECTRUM FOR GAMMA LINES (SAS2)

90.00 DAY TIME OF THE REQUESTED NUCLIDES

ENERGY INTERVAL IN MEV

PHOTONS / SECOND MEV / SECOND

$\begin{array}{ll}1.0000 \mathrm{E}-02 & \text { TO } \\ 5.0000 \mathrm{E}-02 & \mathrm{TO} \\ 1.0000 \mathrm{E}-01 & \mathrm{TO} \\ 2.0000 \mathrm{E}-01 & \mathrm{TO} \\ 3.0000 \mathrm{E}-01 & \mathrm{TO} \\ 4.0000 \mathrm{E}-01 & \mathrm{TO} \\ 6.0000 \mathrm{E}-01 & \mathrm{TO} \\ 8.0000 \mathrm{E}-01 & \mathrm{TO} \\ 1.0000 \mathrm{E}+00 & \mathrm{TO} \\ 1.3300 \mathrm{E}+00 & \mathrm{TO} \\ 1.6600 \mathrm{E}+00 & \mathrm{TO} \\ 2.0000 \mathrm{E}+00 & \mathrm{TO} \\ 2.5000 \mathrm{E}+00 & \mathrm{TO} \\ 3.0000 \mathrm{E}+00 & \mathrm{TO} \\ 4.0000 \mathrm{E}+00 & \mathrm{TO} \\ 5.0000 \mathrm{E}+00 & \mathrm{TO} \\ 6.5000 \mathrm{E}+00 & \mathrm{TO} \\ 8.0000 \mathrm{E}+00 & \mathrm{TO}\end{array}$

TOTALS
5.0000E-02

$1.0000 \mathrm{E}-01$

2.0000E-01

3.0000E-01

4.0000E-01

6.0000E-0 1

8.0000E-01

$1.0000 \mathrm{E}+00$

$1.3300 \mathrm{E}+00$

$1.6600 \mathrm{E}+00$

$2.0000 E+00$

$2.5000 \mathrm{E}+00$

$3.0000 E+00$

$4.0000 \mathrm{E}+00$

$5.0000 \mathrm{E}+00$

$6.5000 E+00$

$8.0000 E+00$

$1.0000 \mathrm{E}+01$
$2.1970 \mathrm{E}+16$

$6.8519 \mathrm{E}+15$

$8.3370 \mathrm{E}+15$

$1.6638 \mathrm{E}+15$

$1.2949 \mathrm{E}+15$

$1.0888 \mathrm{E}+16$

$3.8119 E+16$

$1.7085 \mathrm{E}+15$

$8.0689 \mathrm{E}+14$

$5.4587 \mathrm{E}+14$

$3.7805 \mathrm{E}+13$

$1.6281 \mathrm{E}+14$

$1.0535 \mathrm{E}+13$

2. $9931 E+11$

8. $2902 E+06$

3. $3245 E+06$

$6.5171 \mathrm{E}+05$

1. $3830 \mathrm{E}+05$

$9.2398 D+16$
$6.5911 E+14$

$5.1389 E+14$

$1.2505 E+15$

4. $1594 E+14$

$4.5323 E+14$

$5.4439 \mathrm{E}+15$

$2.6684 E+16$

$1.5376 \mathrm{E}+15$

$9.4002 E+14$

$8.1607 E+14$

$6.9184 \mathrm{E}+13$

$3.6633 E+14$

2. $8972 \mathrm{E}+13$

$1.0476 \mathrm{E}+12$

$3.7306 \mathrm{E}+07$

1.9116E+07

$4.7249 E+06$

$1.2447 \mathrm{E}+06$

$3.9179 D+16$

TOTAL ENERGY FROM NUCLIDES WITH SPECTRUM DATA $=3.9175 E+16$

TOTAL ENERGY FROM NUCLIDES WITH NO SPECTRUM DATA $=4 \cdot 3040 \mathrm{E}+12$

Fig. 3. Photon Spectrum from all Nuclides in a PWR Spent-Fuel Assembly 
10

60-DAY PWR SPENT FUEL

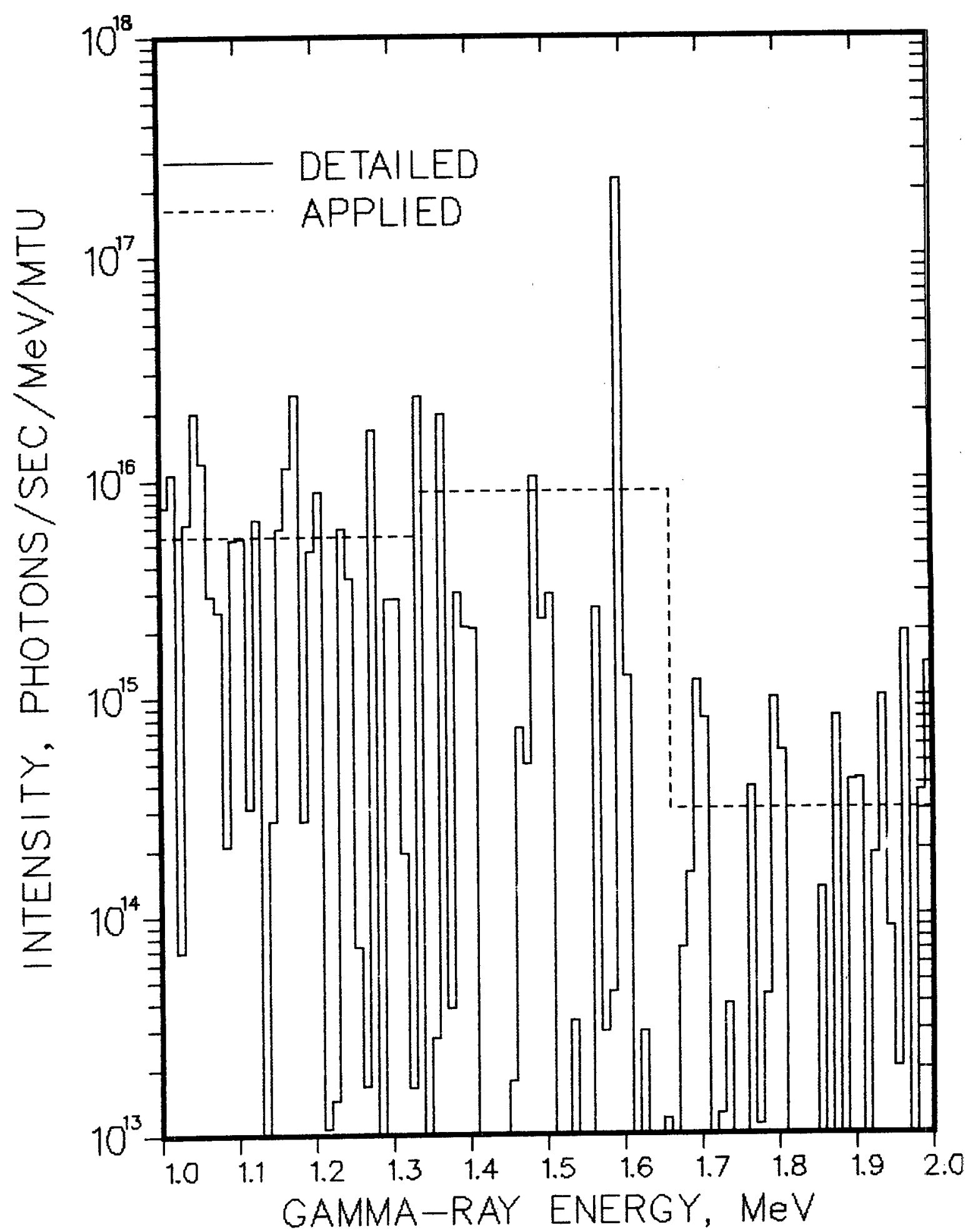

Figure 4. Part of Spectrum, Comparing Intensities for Different Energy-Group Widths. 
551340

4.4700E-038.8868E-043.1817E-022.1321E-033.2194E-023.9337E-03 $3.6400 \mathrm{E}-021.4315 \mathrm{E}-032.4289 \mathrm{E}-012.1000 \mathrm{E}-043.2645 \mathrm{E}-011.4400 \mathrm{E}-04$ $4.7535 \mathrm{E}-011.4600 \mathrm{E}-025.6323 \mathrm{E}-018.3800 \mathrm{E}-025.6932 \mathrm{E}-011.5430 \mathrm{E}-01$ $6.0470 \mathrm{E}-019.7600 \mathrm{E}-017.9584 \mathrm{E}-018.5400 \mathrm{E}-018.0193 \mathrm{E}-018.7300 \mathrm{E}-02$ $1.0386 \mathrm{E}$ 001.0000E-021.1679E 001.8000E-021.3652E 003.0400E-02

571400

4.8400E-032.2854E-032.4600E-024.5869E-063.4279E-024.4351E-03 $3.4720 \mathrm{E}-028.1378 \mathrm{E}-033.9300 \mathrm{E}-023.0301 \mathrm{E}-036.4135 \mathrm{E}-029.5560 \mathrm{E}-05$ $6.8916 \mathrm{E}-026.1158 \mathrm{E}-041.0942 \mathrm{E}-012.0068 \mathrm{E}-031.3112 \mathrm{E}-014.7780 \mathrm{E}-03$ $1.7355 \mathrm{E}-011.2423 \mathrm{E}-032.4197 \mathrm{E}-013.9180 \mathrm{E}-032.6655 \mathrm{E}-014.6824 \mathrm{E}-03$ $3.0690 \mathrm{E}-013.3446 \mathrm{E}-053.2877 \mathrm{E}-011.8539 \mathrm{E}-013.9779 \mathrm{E}-011.0512 \mathrm{E}-03$ $4.3253 \mathrm{E}-012.7235 \mathrm{E}-024.3850 \mathrm{E}-012.0068 \mathrm{E}-044.4600 \mathrm{E}-012.3890 \mathrm{E}-04$ 4.8703E-014.3002E-016 . 1820E-014.2046 E-047 .5183E-014.2046 E-02 $8.1585 \mathrm{E}-012.2457 \mathrm{E}-018.6782 \mathrm{E}-015 \cdot 3514 \mathrm{E}-029.1963 \mathrm{E}-012.5228 \mathrm{E}-02$ $9.2524 \mathrm{E}-016.7848 \mathrm{E}-029.3690 \mathrm{E}-015.7336 \mathrm{E}-049.5140 \mathrm{E}-015.2558 \mathrm{E}-03$ $1.5965 \mathrm{E} \mathrm{009.5560E-012.3481E} \mathrm{008.6004E-032.4653E} \mathrm{001.7201E-04}$ $2.5217 \mathrm{E} \quad 003.4402 \mathrm{E}-022.5334 \mathrm{E} \quad 003.8224 \mathrm{E}-052.5475 \mathrm{E} \quad 001.0512 \mathrm{E}-03$ $2.8997 \mathrm{E} 006.2114 \mathrm{E}-043.1190 \mathrm{E} 002.5801 \mathrm{E}-043.3196 \mathrm{E} \quad 004.4913 \mathrm{E}-05$
0.0
0.0
0.0
0.0
0.0
0.0

591440
$5.2300 \mathrm{E}-030.0$
$3.6847 \mathrm{E}-020.0$
$3.7361 \mathrm{E}-020.0$
$4.2300 \mathrm{E}-020.0$
$6.2466 \mathrm{E}-011.2580 \mathrm{E}-056.7502 \mathrm{E}-013.0636 \mathrm{E}-05$
$6.9649 \mathrm{E}-011.4800 \mathrm{E}-028.1415 \mathrm{E}-013.6260 \mathrm{E}-058.6453 \mathrm{E}-012.8564 \mathrm{E}-05$
$1.3880 \mathrm{E} \quad 006.5860 \mathrm{E}-051.4892 \mathrm{E} \quad 003.0044 \mathrm{E}-031.5620 \mathrm{E} 002.5160 \mathrm{E}-06$
$2.1857 \mathrm{E} 007.7404 \mathrm{E}-032.6546 \mathrm{E} 002.0720 \mathrm{E}-060.0$
0.0

Figure 5. Examples of Data for ${ }^{134} \mathrm{Cs},{ }^{140} \mathrm{La}$ and ${ }^{144} \mathrm{Pr}$ in the Master Photon Data Base. 
spectrum. A sample of the gamma-ray and $x$-ray data in the ORNL Master Photon Data Base is shown in Fig. 5.

\section{NEUTRON SOURCE SPECTRA}

While all of the codes considered in this report compute neutron source strengths, only ORIGEN-S and SAS2 currently are capable of calculating the neutron source spectra. Methods of using neutron sources from ORIGEN2, which are less automatic, are not reviewed here.

\subsection{DESCRIPTION OF SAS2 AND ORIGEN-S NEUTRON SOURCE SPECTRUM MODEL}

The neutron source used by SAS2 and ORIGEN-S includes that produced from both spontaneous fission and (alpha, $n$ ) reactions due to heavy nuclides. The neutrons from photofission and photoneutron reactions are excluded, since it was determined that their intensity is an insignificant part of the spent-fuel sources of interest.

\subsubsection{Spontaneous Fission Neutron Source Strength}

The major part of the neutron source is produced from spontaneous fission of the heavy nuclides. The types of data required to compute the neutron production rate from this process include the spontaneous fission half-life, the average neutron yield per spontaneous fission, $\nu_{s f}$, and the quantity of each contributing nuclide. Spontaneous fission half-lives for the more significant nuclides were taken from Kocher's compilation of ENSDF decay data. ${ }^{14}$ For several less important isotopes, unmeasured half-lives were estimated with a correlation between measurements and so-called fissility parameters. ${ }^{22}$ The $\nu_{\text {sf }}$ data are taken from Ref. 23. Measured $\nu_{s f}$ values are available for 21 nuclides, including the most significant. An equation, derived $^{23}$ to compute $v_{s f}$, produces values which are within two experimental standard deviations for all except three nuclides. This equation is used by SAS2 and ORIGEN-S for those nuclides that do not have measured data.

\subsection{2. (Alpha, $n$ ) Reaction Neutron Source Strength}

A significant part of the neutron source is produced from ${ }^{17} \mathrm{O}($ alpha, $n)$ and ${ }^{18} \mathrm{O}(\mathrm{alpha}, \mathrm{n})$ reactions in the $\mathrm{UO}_{2}$ in the spent fuel. Thin target cross sections and alpha stopping powers are required to properly compute this type of neutron yield. Improved measurements of thin target (alpha, $n$ ) cross sections for ${ }^{17} 0$ and ${ }^{18} 0$ were performed by Bair and del Campo. ${ }^{24}$ Also, their research included the computation of thick target energy-dependent (alpha, $n$ ) yields for $238 \mathrm{UO}_{2}$. with an accuracy estimated to be within 10\%. SAS2 applies these data to weighted energy averages of alpha energy-intensity data.14 Decay constants and alpha branching fractions are taken from the ORIGEN-S library. 


\title{
4.1.2. Computing the Neutron Spectral Distribution
}

\begin{abstract}
Neutrons produced from ${ }^{242} \mathrm{Cm}$ and ${ }^{244} \mathrm{Cm}$ are an extremely large part of the spent fuel neutron source. Calculations of isotopic contributions to the neutron source in spent PWR fuel, during decay times in the range from discharge to 10 years, indicated only a few percent is produced from other nuclides. The next largest contribution was (alpha, $n$ ) production from ${ }^{238} \mathrm{Pu}$. The neutron energy spectra of both the spontaneous fission and (alpha, $n$ ) reactions due to the two curium isotopes ${ }^{25,26}$ and ${ }^{238} \mathrm{Pu}^{27}$ were determined for the isotopic power generator project. The measured spontaneous fission neutron spectrum of $244 \mathrm{~cm}$ was found to be quite similar to that from $235 \mathrm{U}$ and ${ }^{252} \mathrm{Cf}$. Thus, the spectrum for ${ }^{242} \mathrm{Cm}$ was computed ${ }^{25}$ from these measurements. The (alpha, $n$ ) neutron spectra were determined by extrapolating the neutron spectrum from Po- $\alpha-0$ source measurements ${ }^{28}$ to the alpha energies of ${ }^{242} \mathrm{Cm}, 244 \mathrm{Cm}$ and ${ }^{238} \mathrm{Pu}$.
\end{abstract}

The energy distribution of the spontaneous fission neutron spectrum is computed by SAS2 from the spectra for ${ }^{242} \mathrm{~cm}$ and ${ }^{244} \mathrm{~cm}$, described above, using the calculated concentrations of the two isotopes. This spectrum is then renormalized to include the total neutron source from all spontaneously fissioning isotopes. A similar calculation, using the data for all three of the above isotopes, is performed for the (alpha, $n$ ) neutron spectrum. The spectra are collapsed from the energy-groupstructure of the data to that of the SCALE library requested for the shipping cask analysis. The procedure uses uniform distributions within each group and sums the fractional fine-group source values based upon energy fractions common to both groups in the two group-structures. The total neutron source spectrum is then computed as the sum of the spontaneous fission and (alpha, $n$ ) spectra.

Measurements of isotopic spectra, other than those used by SAS2, have been reported ${ }^{29}$ for the dioxides of ${ }^{252} \mathrm{Cf}$ and ${ }^{242} \mathrm{Cm}$. A comparison with the data applied by SAS2 indicates that the differences in the $242 \mathrm{~cm}$ spectrum in the lower neutron energy range are approximately $10 \%$ and those in the higher energy range, which includes the (alpha, $n$ ) produced neutrons, are in the vicinity of $20 \%$.

\subsection{EXAMPLES OF NEUTRON SPECTRA}

Fig. 6 shows the neutron source spectrum of a PWR assembly cooled to 90 days, as computed by SAS2. Even though the lower cutoff of the spectrum is $0.3 \mathrm{MeV}$, the remaining lower energy groups are required in the case for the slowing down of neutrons in the shielding analysis.

Fig. 7 is a plot of a fine-group-structure spectrum of 1 kilogram
of ${ }^{242} \mathrm{Cm}$. It illustrates the larger spontaneous fission peak and the high energy hump along the side of the peak, due to (alpha,n) source production. 
NEUTRON SOURCE BY GROUPS

$\begin{array}{rlll}\text { GROUP } & \text { SPON. FISSION } & (\text { ALPHA, }) & \text { TOTAL } \\ 1 & 4.398 \mathrm{E}+06 & 0.0 & 4.398 \mathrm{E}+06 \\ 2 & 4.864 \mathrm{E}+07 & 9.138 \mathrm{E}+06 & 5.778 \mathrm{E}+07 \\ 3 & 5.276 \mathrm{E}+07 & 1.014 \mathrm{E}+07 & 6.290 \mathrm{E}+07 \\ 4 & 3.022 \mathrm{E}+07 & 1.417 \mathrm{E}+06 & 3.164 \mathrm{E}+07 \\ 5 & 4.143 \mathrm{E}+07 & 5.181 \mathrm{E}+05 & 4.195 \mathrm{E}+07 \\ 6 & 4.575 \mathrm{E}+07 & 9.592 \mathrm{E}+04 & 4.585 \mathrm{E}+07 \\ 7 & 8.991 \mathrm{E}+06 & 1.750 \mathrm{E}+04 & 9.008 \mathrm{E}+06 \\ 8 & 0.0 & 0.0 & 0.0 \\ 9 & 0.0 & 0.0 & 0.0 \\ 10 & 0.0 & 0.0 & 0.0 \\ 11 & 0.0 & 0.0 & 0.0 \\ 12 & 0.0 & 0.0 & 0.0 \\ 13 & 0.0 & 0.0 & 0.0 \\ 14 & 0.0 & 0.0 & 0.0 \\ 15 & 0.0 & 0.0 & 0.0 \\ 16 & 0.0 & 0.0 & 0.0 \\ 17 & 0.0 & 0.0 & 0.0 \\ 18 & 0.0 & 0.0 & 0.0 \\ 19 & 0.0 & 0.0 & 0.0 \\ 20 & 0.0 & 0.0 & 0.0 \\ 21 & 0.0 & 0.0 & 0.0 \\ 22 & 0.0 & 0.0 & 0.0 \\ 23 & 0.0 & 0.0 & 0.0 \\ 24 & 0.0 & 0.0 & 0.0 \\ 25 & 0.0 & 0.0 & 0.0 \\ 26 & 0.0 & 0.0 & 0.0 \\ 27 & 0.0 & 0.0 & 0.0 \\ & & 2.132 \mathrm{E}+07 & \\ & 2.322 \mathrm{E}+08 & & \\ & & 0.535 \mathrm{E}+08\end{array}$

Fig. 6. Neutron Source Spectrum in the 27-Group Structure of a SCALE Library. 


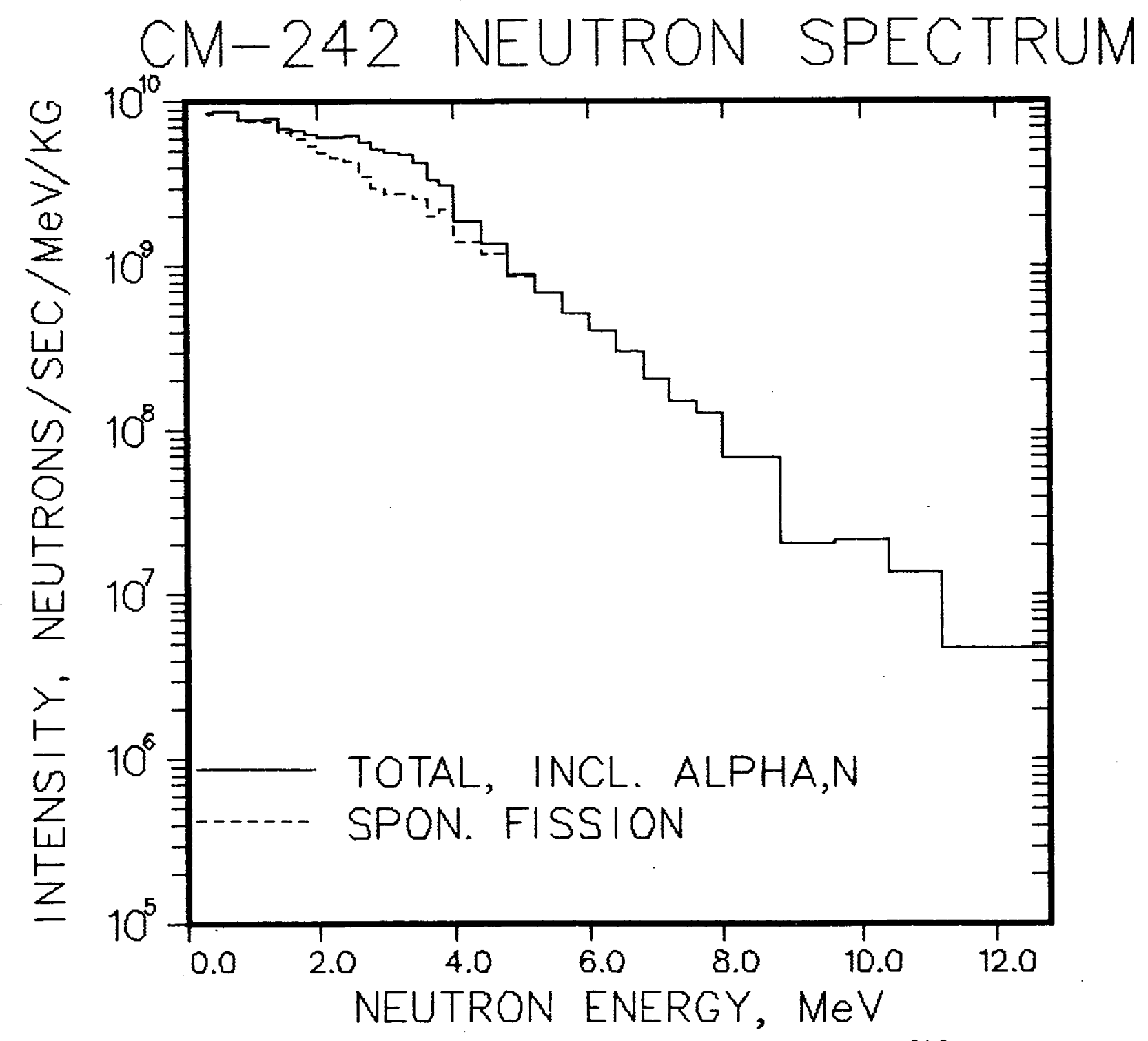

Figure 7. Neutron Source Spectrum from a 1-Kilogram Mass of ${ }^{242} \mathrm{Cm}$. 


\section{RANGE OF APPLICABILITY}

The methods of computing photon and neutron spectra discussed in this report apply only to discharged fuel or other sources outside of the reactor environment. The photon spectra of fuel in an operating reactor include, also, the prompt photon spectra due to ( $n$,gamma), fission and other reactions.

During the first hour, or possibly several hours, after reactor shutdown there is a significant neutron source from photoneutron reactions. At longer cooling times only insignificant fractions of the neutron source are caused by the usual photoneutron target materials, the uranium fuel and the tritium in a water coolant. However, the neutron source spectrum model does not account for a large increase in the tritium or extremely large quantities of $\mathrm{Li},{ }^{9} \mathrm{Be},{ }^{13} \mathrm{C}$ or $\mathrm{F}$.

The photon source is usually dominated by the contributions from fission products, and possibly one or two activation products (e.g.,

${ }^{60} \mathrm{Co}$ ) of the clad and assembly structural materials. The low intensity from high energy photons from the heavy metal isotopes may contribute a comparable fraction to the computed dose rates, only, for long cooling times and extremely thick shields. The calculation of isotopic inventories is more sensitive to cross sections for heavy metals than it is for fission products. Cross-section processing in the depletion analyses are performed with a point depletion model instead of a more complete multidimensional model. Uncertainties in the cross sections, the neutron spectra data and the calculated neutron source strengths cause the computed spectra of the neutrons to have appreciably more uncertainty than that of the photons.

Spent fuel source spectra can be sensitive to the reactor power history. This sensitivity is most pronounced for neutron spectra at either short or long cooling times where the reactor was shut down for a long time during the middle of the fuel's residence time. Also, power histories can be somewhat important for photon spectra computed at short cooling times. Thus, spent fuel source spectra are more correctly described as dependent on: (1) a reactor type, (2) assembly power history, (3) initial ${ }^{235} \mathrm{U}$ enrichment, (4) assembly burnup, and (5) a cooling time.

The dose rates computed for two monoenergetic photon sources shielded with a typical shield thickness are highly dependent on the two photon energies. Adjoint flux calculations have indicated that the ratio of the importance of photons in two adjacent energy groups may be as great as a factor of two or three, for significant groups in a typical 18-group structure. Thus, the benefit of finer group intervals should be properly balanced against computer cost in selecting an appropriate energy-group-structure. Also, the conversion of one photon spectrum having a broad-group-structure to a spectrum of another group structure may significantly reduce its quality. 


\section{CONCLUSIONS}

The methods and, in particular, the data applied in computing photon source spectra described in this report, due to the contributions of numerous researchers, represent a notable achievement in the field of radiation science. Also, there has been a significant improvement over previous methods of computing neutron source spectra. All three of the codes described here, including the data bases, are available from the Radiation Shielding Information Center (ORNL). 


\section{REFERENCES}

1. A. G. Croff, ORIGEN2 - A Revised and Updated Version of the Oak Ridge Isotope Generation and Depletion Code, ORNL-5621 (July 1980).

2. 0. W. Hermann and R. M. Westfall, "ORIGEN-S: SCALE System Module to Calculate Fuel Depletion, Actinide Transmutation, Fission Product Buildup and Decay, and Associated Radiation Source Terms," as described in Section F7 of SCALE: A Modular Code System for Performing Standardized Computer Analyses for Licensing Evaluation, NUREG/CR-0200, Vol. 2 (October, 1981).

3. M. J. Bell, QRIGEN--The ORNL Isotope Generation and Depletion Code, ORNL-4628 (May 1973).

4. 0 . W. Hermann, "SAS2: A Coupled One-Dimensional Depletion and Shielding Analysis Module," as described in Section S2 of SCALE: A Modular Code System for Performing Standardized Computer Analyses for Licensing Evaluation, NUREG/CR-0200, Vol. 1 (1983).

5. A. G. Croff, R. L. Haese, and N. B. Gove, Updated Decay and Photon Libraries for the ORIGEN Code, ORNL/TM-6055 (February 1979).

6. J. C. Ryman, "ORIGEN-S Data Libraries," as described in Section M6 of SCALE: A Modular Code System for Performing Standardized Computer Analyses for Licensing Evaluation, NUREG/CR-0200, Vol. 3 (1983).

7. A. G. Croff, M. A. Bjerke, G. W. Morrison, and L. M. Petrie, Revised Uranium-Plutonium Cycle PWR and BWR Models for the ORIGEN Computer Code, ORNL/TM-6051 (September 1978).

8. A. G. Croff and M. A. Bjerke, Alternative Fuel Crale PWR Models for the ORIGEN Computer Code, ORNL/TM-7005 (February 1980).

9. A. G. Croff and M. A. Bjerke, Once-Through CANDU Reactor Models for the ORIGEN2 Computer Code, ORNL/TM-7177 (November 1980).

10. A. G. Croff, J. W. McAdoo, and M. A. Bjerke, LMFBR Models for the ORIGEN2 Computer Code, ORNL/TM-7176 (October 1981).

11. C. W. Kee, A Revised Light Element Library for the ORIGEN Code, ORNL/TM-4896 (May 1975).

12. C. W. Kee, C. R. Weisbin, and R. E. Schenter, "Processing and Testing of ENDF/B-IV Fission Product and Transmutation Data," Irans. Am. Nucl. Soc. 19, 398-99 (1974).

13. W. B. Ewbank, M. R. Schmorak, F. E. Bertrand, M. Feliciano, and D. J. Horen, Nuclear Structure Data File: A Manual for Preparation of Data Sets, ORNL-5054 (June 1975). 
14. D. C. Kocher, Radioactive Decay Data Tables, ORNL, DOE/TIC-11026 (1981).

15. D. H. Stoddard and E. L. Albenesius, Radiation Properties of $238 \mathrm{Pu}$ Produced for Isotopic Power Generators, DP-984 (July 1965).

16. H. R. Martin, Reaction Gamma Rays in Plutonium Compounds, Mixtures and Allovs, RFP-2832 (June 1975).

17. R. W. Peelle and F. C. Maienschein, The Absolute Spectrum of Photons Emitted in Coincidence with Thermal-Neutron Fission of Uranium-235, ORNL-4457 (April 1970).

18. E. P. Blizard (ed.), Reactor Handbook, 2nd ed., pp. 25-26, Interscience, 1962.

19. N. B. Gove and M. J. Martin, "Log-f Tables for Beta Decay," Nuclear Data Tables. 10, 205-317 (1971).

20. L. T. Dillman, EDISTR - A Computer Program to Obtain a Nuclear Decay Data Base for Radiation Dosimetry, ORNL/TM-6689 (1980).

21. H. H. Van Tuyl, U. S. Atomic Energy Commission Report, HW-83784 (1964).

22. W. J. Swiatecki, Phys, Rev.e 100, p. 937 (1955).

23. D. L. Johnson, Evaluation of Neutron Yields from Spontaneous Fission of Transuranic Isotopes, Hanford Engineering Developing Laboratory, HEDL-SA-973 (1975).

24. J. K. Bair and J. G. del Campo, "Neutron Yields from Alpha-Particle Bombardment," Nucl. Sci. Engr.. 71, p. 18 (1979).

25. D. H. Stoddard, Radiation Properties of $244 \mathrm{Cm}$ Produced for Isotopic Power Generators, Savannah River Laboratory, DP-939 (1964).

26. S. J. Rimshaw and E. E. Ketchen, Curium Data Sheets, ORNL-4357 (January 1969).

27. D. H. Stoddard and E. L. Albenesius, Radiation Properties of $238 \mathrm{Pu}$ Produced for Isotopic Power Generators, Savannah River Laboratory, DP-984 (July 1965).

28. A. G. Khabakhpashev, "The Spectrum of Neutrons from a Po- $\alpha-0$ Source," Atomnaya Energiya, 7, p. 71 (1959).

29. N. D. Tyufyakov, et al., "Investigation of Spectral Characteristics of Neutron Sources Based on ${ }^{238} \mathrm{Pu},{ }^{244} \mathrm{Cm}$ and ${ }^{252} \mathrm{Cf}$, "Radiation Technology, Issue 5, Trudy Instituta, Moscow, USSR (1970) (Translated for the AEC and NSF by Franklin Book Programs, Inc.; Available from the NTIS, U. S. Department of Commerce, Springfield, Virginia), pp. 86-93 $(1970 / 1975)$. 
ORNL/CSD/TM-205

Distribution Category: GM

\section{INTERNAL DISTRIBUTION}

1. G. E. Whitesides/R. P. Leinius/ C\&TD Library

2-6. C. W. Alexander

7. R. C. Ashline

8. B. L. Broadhead

9. J. A. Bucholz

10. T. J. Eurns

11. A. G. Croff

12. W. E. Ewbank

13-17. 0. W. Hermann

18. J. V. Pace, III

19-23. C. V. Parks

24. L. M. Petrie

25. J. P. Renier

26. J. W. Roddy

27. J. C. Ryman
28. D. L. Selby

29. L. B. Shappert

30. C. 0. Slater

31. J. S. Tang

32. D. R. Vondy

33. C. R. Weisbin

34-38. R. M. Westfall

39. B. A. Worley

40. R. Q. Wright

41. C. R. Library

42. Document Reference Section $\mathrm{Y}-12$

43-44. Laboratory Records

45. Laboratory Records - RC

46. ORNL Paterit Section

\section{EXTERNAL DISTRIBUTION}

47. J. N. Rogers, Div. 8474, Sandia National Laboratorles, Livermore, CA 94550

48. Division of Engineering, Mathematics and Geosciences, U. S. Department of Energy, Washington, DC 20545

49. Office of Assistant Manager for Energy Research and Development, U. S. Department of Energy, Oak Ridge Operations, Oak Ridge, TN 37830

50. J. A. Lenhard, U. S. Department of Energy, Oak Ridge Operations, Oak Ridge, TN 37830

51. S. Anghoie, Department of Nuclear Engineering Sciences, 202 Nuclear Sciences Cencer, University of Florida, Gainesville, FL 32611

52. A. T. Clark, Office of Nuclear Material Safety \& Safeguards, U. S. Nuclear Regulatory Commission, Mail Stop 396-SS, Washington, DC 20555

53. Jack Courtney, Nuclear Science Center, Baton Rouge, LA 70803

54. R. H. Odegaarden, Transportation and Certification Branch, Office of Nuclear Material Safety \& Safeguards, Nuclear Regulatory Commission, Mail Stop 396-SS, Washington, DC 20555

55. R. E. Schenter, Hanford Engineering Development Laboratory, F. O. Box 1970, Richland, WA 99352

56. Carl Heeb, Battelle-PNL, P. O. Box 999, Richland, WA 99352

57. Urban Jenquin, Battelle-PNL, P. O. Box 999, Fichland, WA 99352

58. R. E. Glass, Sandia National Laboratories, P. O. Rox 5800, Division 6322, Albuquerque, NM 87185

59. C. Marotta, Transportation and Certification Eranch, Office of Nuclear Material Safety \& Safeguards, Nuclear Regulatory Commission, Mail Stop 396-SS, Washington, DC 20555

60. E. Easton, Transportation and Certification Branch, office of Nuclear Material Safety \& Safeguards, Nuclear Regulatory Commission, Mail Stop 396-SS, Washington, DC 20555

61-87. Technical Information Center, U. S. Department of Energy, Oak Ridge, TN 37830 